\title{
Social Studies Learning With Numbered Head Together Model Improves Learning Outcomes Viewed From Student Learning Motivation
}

\author{
Ni Komang Sriwati ${ }^{1}$, Ni Ketut Suarni ${ }^{2}$ \\ ${ }^{1}$ Primary School Teacher Education Study Program, Department of Basic Education, Undiksha, Indonesia \\ ${ }^{2}$ Counseling Guidance Study Program, Department of Education, Psychology and Guidance, Undiksha, Indonesia \\ ${ }^{3}$ Primary School Teacher Education Study Program, Department of Basic Education, Undiksha, Indonesia
}

\section{A R T I C LE IN F O}

Article history:

25 December 2019

Received in revised form 01 January 2020

Accepted 25 January 2020

Available online 28

February 2020

kata kunci:

model NHT, hasil belajar,

motivasi

keywords:

model NHT, learning

outcomes, motivation

\begin{abstract}
A B S T R A K
Belum optimalnya hasil belajar IPS siswa kelas V SD di Gugus XI Kecamatan Buleleng menjadi alasan utama dilakukannya penelitian ini. Penelitian ini bertujuan untuk menganalisis pengaruh model pembelajaran numbered head together (NHT) berbantuan media audio visual terhadap hasil belajar IPS ditinjau dari motivasi belajar siswa kelas V. Jenis penelitian ini adalah quasi eksperimen dengan non equivalent post-test only control group design. Populasi dalam penelitian ini adalah kelas V SD. Sampel dalam penelitian ini yaitu kelas VB SD Lab Undiksha yang berjumlah 35 siswa dan VA SD Lab Udiksha yang berjumlah 35 siswa. Metode pengumpulan data yang digunakan adalah metode tes pilihan ganda dan metode non tes dalam bentuk kuesioner. Data hasil belajar yang diperoleh dianalisis menggunakan Anava dua jalur. Hasil penelitian menunjukkan bahwa, terdapat perbedaan hasil belajar IPS antara siswa yang dibelajarkan dengan model pembelajaran NHT berbantuan media audio visual dengan siswa yang dibelajarkan model pembelajaran konvensional. Terdapat pengaruh interaksi antara model pembelajaran NHT
\end{abstract} berbantuan media audio visual dengan motivasi belajar terhadap hasil belajar IPS siswa. Terdapat perbedaan hasil belajar IPS antara siswa yang dibelajarkan dengan model pembelajaran NHT berbantuan media audio visual dengan siswa yang dibelajarkan model pembelajaran konvensional pada siswa yang mempunyai motivasi belajar tinggi. Terdapat perbedaan hasil belajar IPS antara siswa yang dibelajarkan dengan model pembelajaran NHT berbantuan media audio visual dengan siswa yang dibelajarkan model pembelajaran konvensional pada siswa yang mempunyai motivasi belajar rendah. Sehingga dapat disimpulkan bahwa model pembelajaran NHT berbantuan media audio visual berpengaruh positif terhadap hasil belajar IPS ditinjau dari motivasi belajar siswa.

\section{A B S T R A C T}

The lack of optimal learning outcomes of social studies for fifth-grade elementary school students in Cluster XI Buleleng District is the main reason for this research. This study aims to analyze the effect of numbered head together (NHT) learning models, assisted by audio-visual media on social studies learning outcomes in terms of the learning motivation of fifth-grade elementary school students. Types of this research is a quasi-experiment with a non-equivalent post-test only control group design. The population in this study was grade $\mathrm{V}$ elementary school. The sample in this study was the VB class at SD Singaraja Lab of 35 students and VA class at SD Lab Singaraja of 35 students. Data collection methods used were of multiple-choice tests and non-test methods in the form of questionnaires. Learning outcomes data obtained were analyzed using Anava two pathways. The results showed that there were differences in social studies learning outcomes between students who were taught with the NHT model assisted by audiovisual media and students who were taught conventional learning models, there was an interaction effect between the learning model of NHT assisted with audiovisual media with learning motivation towards students' social studies learning outcomes, there was the difference in social studies learning outcomes between students who are taught with the NHT model assisted by audio-visual media and students who were taught conventional learning models to students who have high learning motivation, there was the difference in social studies learning outcomes between students who are taught with the NHT model assisted by audio-visual media and students who were taught conventional learning models to students who have low learning motivation. Based on the results of the study it can be concluded that the numbered head together learning model assisted by audiovisual media has a positive effect on social studies learning outcomes in terms of the learning motivation of students.

Copyright (c) Universitas Pendidikan Ganesha. All rights reserved. 


\section{Introduction}

Social Studies is a subject that explores social structures including some subjects which reflect the social problems in our society (Wahida, et al., 2019). The aim of Social Studies learning is to increase the students' ability and creativity in facing the social problems they or other people have and to develop a positive attitude toward fixing social inequality (Susanto, 2014). This is in line with Fauziah (2018) who stated that by learning social studies, students will be good and responsible citizens and can develop social creativity to resolve social problems. In a nutshell, it is believed that Social Studies is needed to be taught since elementary school, so that the students can solve the social problems that exist in their environment, can interact well, and of course build them into a good citizen, democratic, and responsible in the future. To be able to reach the goal of social studies, students' support is needed through students' learning motivation.

Learning motivation is the feeling of support that every student has in the learning activity to gain the optimum learning result (Utami, et al., 2018). The motivations are different. Some students have high motivation. There are students with low motivation. The students with high motivation have an intention to gain high learning outcomes. Students with low motivation are intended to gain low learning outcomes (Nugraha, et al., 2017). This is in line with Sardiman (in Trisnawati, et al., 2019) who argues that if there is any good motivation in learning, the students will get good results as well. Thus, students' learning motivation needs to be observed.

Unfortunately, the status quo says that the learning process of social studies is not optimum yet. It is stated by Astuti (2019) the lack of optimal learning process of social studies is caused by the students' lack of interest in learning the subject. Most students are less responsive; they feel bored in the class since the teacher teaches only using the conventional method without any variation of learning models. The lack of models innovation teachers used in teaching social studies also becomes one of the factors of the students' lack of interest; the students can only memorize the material since the only one source in the class is the teacher himself (Selamet, et al. ,2017). It directly influences students' learning outcomes. It is supported by the observation result which was done in the fifth grade of an elementary school of Gugus XI Buleleng Sub-district. It was found that: (1) Social Studies was observed as one of the lack of optimal subjects to be learned, (2) lack of students' motivation, (3) the group discussion was rarely to be found in the classroom activities, (4) some of the students who were having lack of self-confidence in presenting the work they have finished.

The finding was supported by interview result which shows that some problems exist, such as (1) students chose to memorize instead of understanding the material, (2) there are lack of varied and innovative learning models the teacher used which leads to the students' lack of interest, (3) the teacher does not use the media when the teaching and learning are conducted which makes the students bored, not interactive, and not interested towards the learning process, (4) students are not motivated in doing difficult homework, (5) students' attention is not in the learning and choose to pay with their classmates, (6) smart students do not want to teach their friends who need helps in learning, and (7) smart students are the only one who does the job in the group discussion. Moreover, supported by a literature study, it shows that most of the students' learning outcomes are reflected in the passing grade mark with fair criteria, so the students' learning outcomes are considered not optimal.

If the problems are not handled well, the learning process will be influenced especially towards the students' learning outcomes. The solution to these problems is implementing innovative and varied learning models, one of them is the Numbered Head Together learning model. It is in line with Widyaningtyas, et all. (2018) who states that the cause of the lack of optimum social studies learning outcomes is the irresponsibility of the students in attending the learning process. The solution is to apply innovative learning activity which is Numbered Head Together (NHT), the learning model.

According to Siregar, et all. (2019) NHT is a learning model that requires students to be divided into a group and each student is given a number, then the teacher will call the number randomly. Istarani (in Iqbal, et al., 2017) believe that NHT learning model implementation uses the group to transfer material to unite the students regarding the questions given, then the students will be responsible to present discussion results based on the number called by the teacher. In conclusion, the NHT learning model is a cooperative learning model which uses number on each student that in its implementation, giving the students equal chances in answering and presenting the questions given by the teacher in front of the class.

Hasmyati (2017) states that NHT is the most right on target and potential learning methods to be implemented in learning activities because it requires the students to cooperate in researching and finding information based on the discussed material. It is believed that varied arguments in the discussion will enrich the students' understanding. Setianingsih, et al. (2019) state that NHT requires 
the students to be able to cooperate in a group, with an expectation that all members will get the answers of the task and be responsible for the task given which will make the students actively interactive in the learning process. It can be concluded that NHT leads the students to be active and responsible in the learning process, because, each student must state the arguments in answering problems given. Moreover, the student will gain more understanding of the material because he can learn from his peer. This also grows the readiness of the students in learning, because, the students are required to be ready to either discuss or present the discussion result which will be reflected in their learning outcomes later. According to Trianto (2010:82) "there are 4 phases in implementing the NHT learning model which are: numbering phase, questioning phase, thinking together phase, and answering phase". Erlinda \& Nastuti (2018) state that the character of the NHT model is there is an appointment of the students randomly to represent the group, without telling who will be pointed out. Seeing from the definition NHT learning model can be implemented in the learning process. Nuryanti \& Mustapa (2018) state that the implementation of NHT can make the students active and creative and feel happy and excited to learn because the learning focuses on the students. According to Sugiyadnya, et all. (2019) the advantages of this model are: (1) the students' achievement is increasing, (2) train the responsibility of the students, (3) able to enrich the students' understanding, (4) increase the students' confidence, (5) increase the students'motivation in mastering the learning material.

Some researchers believe that NHT influences learning outcomes. Rahayu \& Suningsih (2018) conducted research entitled The Effects of Type Learning Model Numbered Head Together and Think Pair Share which the result shows the average learning of students' mathematics learning outcomes of the experiment group is higher than the outcomes of the control group. Other research was conducted by Sugihatno \& Slamet (2017), entitled Realistic Matematic Approach through Numbered Head Together Learning Model. The result showed that the use of the NHT model with the RMA approach gives better mathematics learning outcomes than direct learning outcomes. The present research was conducted by fusing the NHT model implementation with audiovisual media in its implementation which becomes the uniqueness of it. Based on the statement, it is believed that a hypothesis can be drawn which is the NHT model influences the learning outcomes.

The NHT learning model was fused with media in its implementation. Karina (2017) believes that learning media is a tool used to deliver a message or teacher's information to the students. The media which deemed suitable was fused with the NHT model is audiovisual media. According to Oktaviani, et all. (2019:2) "audiovisual media is one of the electronic media which is the fuse of electronic media and audio and visual". "Audiovisual media is a media which shows audio and moving pictures that can be used multiple times" (Rositayani, et al., 2018:340). In conclusion, audiovisual media is a media that has audio and pictures that can show objects and events as in reality. Rositayani (2018) believes that the use of audiovisual can help the students in constructing their knowledge by taking advantage of moving pictures and audio as the learning material delivery. This statement is in line with Setianingsih, et all. (2019) who stated that the use of audiovisual media can attract interest and motivate the students in the learning process. It can be said that by using the media, the material can be delivered well and hit the target, thus, the students easily understand the material. Besides, using audiovisual which provides not only sound but also moving pictures will make the students interested in attending the learning process.

The aims of this research were: firstly, to investigate the differences of social studies learning outcomes between students who were taught using NHT with audiovisual media and students who were taught using the conventional model on the grade $\mathrm{V}$ students of the elementary school academic year 2019/2020. Secondly, to investigate the interaction influence between the students who were taught using the NHT model with audiovisual media and the students who were taught by using the conventional method. Thirdly, to investigate the highly motivated students' social studies learning outcomes differences between students who were taught using NHT with audiovisual media and the students who were taught using the conventional method. Fourthly, to investigate the social studies learning outcomes differences between low motivated students who were taught using the NHT model with audiovisual media and the students who were taught by the conventional method.

\section{Methodology}

The present research is experimental. The variables of this research could not be controlled strictly, thus, the research is categorized as pseudo-experimental research. The design of this research was a non-equivalent post-test only control group. The research design used was a two-lane variant analysis (Anava $\mathrm{AB}$ ) with a $2 \times 2$ factorial. 
The population of this research was the grade V elementary school of Gugus XI Buleleng Subdistrict. The total students were 129 who were divided into 5 classes, namely, grade V SDN 1 Kampung Bugis (25), grade V SDN 1 Kampung Anyar (17), grade V SDN 3 Kampung Anyar (17), and grade VA SD Lab Singaraja (35) and grade VB SD Lab Singaraja (35). The sample of this research was taken from random sampling techniques by lottery. Before determining the sample, the equality test was carried out using a one-way analysis of variance (Anava A). The test criterion is if Fcount> from Ftable, then $\mathrm{HO}$ is rejected and H1 is accepted, so the group is interpreted unequally. If Fcount <from Ftable, then $\mathrm{HO}$ is accepted and $\mathrm{H} 1$ is rejected, so the group is interpreted equally. Based on the results of the equality test obtained Fcount <from Ftable so that the group was interpreted as equal. After conducting the equality test continued with the determination of the sample using random sampling techniques by lottery. Based on the lottery results obtained two classes used as research samples namely Singaraja VB Lab class totaling 35 students as an experimental group who were treated with a numbered head together learning model assisted by audiovisual media and VA class totaling 35 students as a control group studied with conventional learning model.

The data in this research was the data about social studies learning outcomes and students' motivation. The method of data collection used test methods in the form of multiple-choice tests of 30 items. Multiple-choice tests are conducted to measure students' knowledge in the cognitive realm. Multiple-choice tests are first validated by experts in charge of social studies, then tested, then conducted tests of validity (content and items), reliability, different power, and level of difficulty. While the learning motivation data collection method uses the non-test method in the form of a questionnaire of 30 items. The questionnaire was conducted to measure student motivation. The questionnaire was first validated by experts in the field of motivation, then tested, then tested the validity (content and items) and reliability.

The data obtained were then analyzed using descriptive statistics and inferential statistics. Descriptive statistics are performed to determine the high and low quality of learning outcomes, both the experimental group and the control group. The descriptive statistical analysis used is the mean, median, mode, standard deviation, and variance. To determine the quality of students' social studies learning outcomes, the average score of each variable is converted using the ideal average criteria (Mi) and the ideal standard deviation (SDi). Meanwhile, the inferential statistical analysis used to test the hypothesis is Anava two paths (Anava $\mathrm{AB}$ ). Before conducting a hypothesis test using Anava $\mathrm{AB}$, a pretest is required. The prerequisite tests that must be met are the normality test and the variance homogeneity test. After the prerequisite tests are fulfilled, it is continued by testing the hypotheses using two paths analysis of variance (Anava $A B$ ). If the two-way Anova test shows $\mathrm{H} 1$ namely there is a difference in social studies learning outcomes between students who are taught with the learning model of the numbered head together assisted with audiovisual media and students who are taught conventional learning models, as well as the interaction between numbered head learning models assisted by audiovisual media with motivation to learn, then proceed with the Tukey test to find out which group is superior.

\section{Findings and Discussion}

Research data that has been collected then tabulated following the needs of the analysis. From the research design used, the data description presented consisted of six groups: (1) students 'social studies learning outcomes in the experimental group (A1), (2) students' social learning outcomes in the control group (A2), (3) learning outcomes Social studies students in the experimental group who have high learning motivation (A1B1), (4) Social learning outcomes of students in the control group who have high learning motivation (A2B1), (5) Social learning outcomes of students in the experimental group who have low learning motivation (A1B2 ), (6) Social studies learning outcomes of students in the control group who have low learning motivation (A2B2). The recapitulation of the Social Studies learning outcomes score description is presented in table 1 below.

Table 1. Recapitulation of the Description of Social Studies Learning Outcomes Scores for Students

\begin{tabular}{lllllll}
\hline Statistic & \multicolumn{7}{c}{ Data } \\
\cline { 2 - 7 } & $\mathbf{A}_{\mathbf{1}}$ & $\mathbf{A}_{\mathbf{2}}$ & $\mathbf{A}_{\mathbf{1}} \mathbf{B}_{\mathbf{1}}$ & $\mathbf{A}_{\mathbf{1}} \mathbf{B}_{\mathbf{2}}$ & $\mathbf{A}_{\mathbf{2}} \mathbf{B}_{\mathbf{1}}$ & $\mathbf{A}_{\mathbf{2}} \mathbf{B}_{\mathbf{2}}$ \\
\hline Mean & 24,37 & 21,83 & 27,42 & 21 & 20,92 & 22,75 \\
Median & 25 & 22 & 27,5 & 21 & 21 & 23 \\
Modus & 26 & 21 & 27 & 20 & 21 & 22 \\
Standar Deviasi & 3,06 & 2,51 & 1,31 & 1,54 & 1,73 & 1,42 \\
Varian & 9,36 & 6,32 & 1,72 & 2,36 & 2,99 & 2,02 \\
\hline
\end{tabular}




\begin{tabular}{lllllll}
\hline Range & 11 & 10 & 5 & 6 & 7 & 6 \\
Minimum & 19 & 18 & 25 & 19 & 18 & 20 \\
Maximum & 29 & 27 & 29 & 24 & 24 & 25
\end{tabular}

Based on the results of the descriptive analysis in table 1 above, it can be seen that the average social studies learning outcomes of the experimental group (A1) are 24.37 which are in the very good category, while the average social studies learning outcomes of the control group is 21.83 that are in the good category. This shows that the average social studies learning outcomes of the experimental group were higher than the control group. The average social studies learning outcomes of the experimental group that has high learning motivation (A1B1) is 27.42 which is in the very good category, while the average social learning outcomes of the control group that has high learning motivation (A2B1) is 20.92 located in either category. This shows that the average social studies learning outcomes of the experimental group that has high learning motivation is higher than the control group that has high learning motivation.

While the average social studies learning outcomes of the experimental group that have low learning motivation (A1B2) is 21 in the good category, while the average social learning outcomes of the control group that has low learning motivation (A2B2) is 22.75 in the category very good. This shows that the average social studies learning outcomes of the control group that have low learning motivation are higher than the experimental group that has low learning motivation. Before proceeding to the hypothesis test, the prerequisite test is performed first. Prerequisite tests that must be met are normality and homogeneity tests. Based on the prerequisite tests that have been carried out using the help of SPSS 17.0 for windows, with the criterion testing a significance value of $>0.05$ (sig,> 0.05 ) shows that learning outcomes in the six data groups are normally distributed and homogeneous. After conducting the prerequisite test continued with the research hypothesis test using a two-path analysis of variance (Anava $\mathrm{AB}$ ). Overall testing of the research hypothesis was carried out using Anava two paths $(\mathrm{AB})$ at a significance level of $5 \%$ with the testing criteria if the significance value (sig. $<0.05$ ), then it was stated there were differences and there were interactions. Hypothesis testing is done with the help of SPSS 17.0 for windows programs. The summary of the two-way Anava calculation is presented in table 2 below.

Table 2. Anava Hypothesis Test AB

\begin{tabular}{lccccc}
\hline \multicolumn{1}{c}{ Sumber Variasi } & JK & Db & RJK & F & Significance \\
\hline A & 67,687 & 1 & 67,687 & 29,758 & 0,000 \\
B & 63,021 & 1 & 63,021 & 27,706 & 0,000 \\
Inter AB & 204,188 & 1 & 204,188 & 89,768 & 0,000 \\
Dal & 100,083 & 48 & 2,275 & & \\
Total & 434,979 & & & & \\
\hline
\end{tabular}

Based on table 2 above shows: (1) F value of 29.758 with a significance value of 0.00 . These results indicate a significance value smaller than 0.05 (sig. <0.05), so it can be concluded that there are differences in social studies learning outcomes between students who are taught with numbered head together learning models assisted by audio-visual media and students who are taught conventional learning models in class V students of Elementary School Academic Year 2019/2020, (2) F value of 89.768 with a significance value of 0.00 . These results indicate a significance value smaller than 0.05 (sig. <0.05), so it can be concluded that there is an influence of interaction between the numbered head together learning model assisted by audiovisual media with learning motivation towards social studies learning outcomes of fifth-grade elementary school students 2019/2020 lessons, (3) F value of 27,706 with a significance value of 0.00 . These results indicate a significance value smaller than 0.05 (sig. $<0.05$ ), so it can be concluded that there are differences in social studies learning outcomes between students who are taught with numbered head together learning models assisted by audio-visual media and students who are taught with learning models conventional for students who have high learning motivation, (4) $\mathrm{F}$ value of 27.706 with a significance value of 0.00 . These results indicate a significance value smaller than 0.05 (sig. <0.05), so it can be concluded that there are differences in social studies learning outcomes between students who are taught with numbered head together learning models assisted by audio-visual media and students who are taught with learning models conventional in students who have low learning motivation. 
The first hypothesis test has successfully rejected $\mathrm{H} 0$ and accepted $\mathrm{H} 1$, this means that there are differences in social studies learning outcomes between students who are taught with the numbered head together learning model assisted by audio-visual media and students who are taught conventional learning models in fifth-grade students of Elementary School 2019/2020. According to Wijayanto (2017), learning outcomes are behavioral changes that involve attitudes, skills, and knowledge received by individuals after going through a process. The factors that influence learning outcomes are internal factors and external factors. One external factor that influences learning outcomes is the learning model (Susanto, 2014). According to Joyce et al. (In Tayeb, 2017) using the learning model, the learning process becomes more effective, because the teacher can guide and direct students to find information, ideas, skills, ways of thinking, and express themselves. The numbered head together learning model enables students to actively find their knowledge by searching for answers to given assignments and be able to deepen their understanding through answering the questions given, and being able to take responsibility for the given tasks. In accordance with the advantages of the NHT learning model according to Sugiyadnya, et all. (2019) that is, train the attitude of responsibility in students and be able to deepen student understanding. In line with the opinion of Hasmyati (2017) states NHT is the most appropriate and potential learning method to be applied in learning activities because it requires students to work together in finding and finding information in accordance with the discussion material. Various kinds of opinions in the discussion increase student understanding. This is in line with research conducted by Trisianawati (2018) which states, with the application of the NHT model when the student learning process is actively involved. The activeness of students is seen when conducting discussions in answering the questions given. Learning by using the numbered head together learning model assisted by audiovisual media in the experimental class consists of 4 phases, namely numbering, asking questions, thinking together, and answering. In line with the opinion of Trianto (2010: 82) which states, "there are 4 phases of the numbered head together learning model namely: the numbering phase, the phase of asking questions, the phase of thinking together, and the phase of answering".

At the numbering phase, the teacher forms students into groups of 3-5 people. Each student is given a different number according to the number of group members. Then the teacher will display a video. The use of audio-visual media, especially video provided at the beginning of learning and adapted to learning material can attract students' attention in learning and give students initial knowledge about the material to be studied, so students better understand learning material and can certainly foster student motivation. In line with Utama, et all. (2019) which states, through video media can help students better understand the material because through video media students are closer to what is learned, so students do not only imagine an abstract material. The second stage asks questions, at this stage the teacher gives questions in the form of worksheets with a specific time limit to each group. By giving questions that are appropriate to the learning material and daily life of students, it will certainly make students more excited and interested in learning and can improve students' critical thinking skills. In line with Purwati, et all. (2019) which states, with active teachers giving questions can guide students to improve critical thinking skills of a simple problem that is commonly found in students in everyday life so that it will improve the ability to analyze and the ability to conclude students. The next stage is the phase of thinking together, at this stage students share information and express their opinions in answering questions and making sure each member knows the answers and allows students to learn from their friends. In line with the opinion of Paramita, et all. (2016) which states, the strength of the NHT model is that in discussing activities students who are smart can teach their friends who are less smart so that all group members can understand the material being studied. This phase provides opportunities for students to explore their knowledge and actively seek answers to the problems given. The last stage is the answer phase, at this stage, the teacher calls student numbers randomly to present the results of the discussion. Students whose numbers are called forward to the front of the class present the results of the discussion. Random number calling aims to guide students to always be ready and better understand the material and be serious in learning, and of course increase student confidence. In line with the opinion of Paramita, et all. (2016) which states, the learning model of the numbered head together makes all students ready and serious in conducting discussions because of the random number designation.

This study is in line with research conducted by Mahardika (2018) with the title "The Effect of Numbered Heads Together Learning Model Against Social Learning Outcomes in Class V Students of Kintamani V Cluster V School Year 2017/2018 Academic Year". The results of his study showed that there was a significant difference in social studies learning outcomes between groups of students who were taught the NHT learning model and groups of students who were taught conventional learning models in class V students of the Kintamani V Cluster V School year 2017/2018. In line with Sugiyad's 
opinion (2019) which states, there is a significant difference in the competence of mathematical knowledge between groups taught with the NHT model and students who are taught the conventional model. Based on the results of the first hypothesis test and supported by relevant research it can be concluded that the learning outcomes of students who are taught with the learning model numbered head together assisted with audiovisual media are better than students who are taught with conventional learning models.

The second hypothesis has succeeded in rejecting $\mathrm{HO}$ and accepting $\mathrm{H} 1$, this means that there is an effect of interaction between the numbered head together learning model assisted by audiovisual media with learning motivation towards social studies learning outcomes of fifth-grade elementary school students in 2019/2020 Academic Year. Based on the results of hypothesis testing, it shows that students who have high learning motivation who are taught with a numbered head together learning model assisted by audiovisual media are better at optimizing social studies learning outcomes than conventional learning models, this can be seen from the average social studies learning outcomes of students who have high motivation learned with the numbered head together learning model assisted by audiovisual media is higher than the average social studies learning outcomes of students who have high learning motivation who are taught with conventional learning models. Whereas students who have low learning motivation who are taught with conventional learning models are better at optimizing learning outcomes than numbered head together learning models assisted by audiovisual media, this can be seen from the average social learning outcomes of students who have low learning motivation who are taught the numbered head together learning model assisted by audiovisual media is lower than the average social studies learning outcomes of students who have low learning motivation who are taught with conventional learning models.

The use of the numbered head together learning model assisted by audiovisual media allows all students to be active and directly involved in the learning process, so students can explore their knowledge through answering the questions given. Besides that, assisted by audio-visual media especially video can make students interested and interested in learning, to increase student motivation in learning. Learning motivation is the feeling of encouragement that each student has in learning activities to obtain the desired learning outcomes (Utami, et al., 2018). Learning motivation can also be influenced by internal and external factors. One external factor that affects student motivation is the learning model. The learning model applied certainly has a different effect on each student because students have different learning motivations. Therefore the use of learning models must pay attention to the characteristics of students, one of them by paying attention to student motivation. According to Kistian (2018) states, the application of the NHT model in mathematics learning can attract the attention of students, able to stimulate students actively in learning and motivate students in learning, because this model is student-centered.

The numbered head together learning model assisted by audiovisual media is more suitable to be applied to students who have high learning motivation, because students who have high learning motivation will be more receptive to learning material, tend to have high curiosity, have a high interest in learning, and happy to solve existing problems, so that student learning outcomes can also improve. Meanwhile, students who have low learning motivation will be more difficult to accept learning material, because students tend not to want to know, do not have a high interest in learning, pay less attention to learning, and are less interested in solving existing problems, so student learning outcomes also tend to be low. This is in line with Sardiman, A.M. (2011: 75) which states "learning outcomes will be optimal if there is the right motivation". Whereas in conventional learning during the learning process in class, the teacher is seen still often explaining the learning material in detail and interspersed with certain questions. So students who have low learning motivation prefer to be taught with conventional learning models because students prefer to hear explanations from the teacher than students who study on their own. Students who have low motivation to learn, are not happy in facing difficulties, do not like working independently must always be given guidance, not happy to find or solve problems, and do not have a high curiosity. So it needs the role of the high teacher in encouraging and guiding students who have low learning motivation when studying.

This study was strengthened by research conducted by Ali (2018), with the title research Effect of Learning Models and Physics Learning Motivation on Physics Learning Outcomes (Experimental Study of Students in Class VIII of SMP Negeri 40 Bulukumba). The results showed: (1) there were differences in physics learning outcomes between students being taught with contextual and conventional learning models in class VIII 40 Bulukumba State Junior High School, (2) for high physics learning motivation, there were differences in physics learning outcomes between students being taught through contextual and conventional learning models in class VIII 40 Bulukumba State Junior High School, (3) for low physics learning motivation, there are differences in physics learning 
outcomes between students taught through contextual and conventional learning models in class VIII 40 State Junior High School Bulukumba and, (4 ) there is an influence of interaction between the learning model with the motivation to study physics on the learning outcomes of students in physics VIII grade SMP Negeri 40.

The third hypothesis has succeeded in rejecting $\mathrm{HO}$ and accepting $\mathrm{H} 1$, this means that there are differences in social studies learning outcomes between students who are taught with the numbered head together learning model assisted by audiovisual media and students who are taught conventional learning models in students who have high learning motivation. The application of the numbered head together learning model assisted by audiovisual media to students who have high learning motivation gives students space to be actively involved in the learning process and provides the broadest opportunity to find their knowledge through given problems, and provide opportunities for students to develop the attitude of responsibility, as well as freedom for students to interact with their friends. In line with the opinion of Widyaningtyas, et all. (2018) states numbered head together is a learning model that aims to increase student participation and activity in learning activities, to practice student skills in making decisions, and provide opportunities for students to interact with friends who come from different backgrounds. By assisting video media in applying the numbered head together learning model it can make students more interested and enthusiastic in learning so that students' motivation increases. Therefore students who have high learning motivation are more pleased to be taught with a numbered head together learning model assisted by audiovisual media, because students who have high learning motivation are happier to learn when given problems to be solved, besides that students who have high learning motivation have a sense of wanting to know the high, tenacious in facing difficulties, and happy in solving a problem. In line with Suratdeni, et al., (2016) which states, students who have high learning motivation have high desires, ideals, and high competition spirit, and realize the importance of learning for themselves. Students who have high learning motivation, if taught with conventional models, students will feel bored, because students only listen to the material provided by the teacher, besides learning with conventional models is less challenging and gives students less opportunity to explore their knowledge.

The results of this study are supported by relevant research that is the research conducted by Mardyastuti (2016), while the results of the research conducted are: 1) the learning outcomes of Natural Sciences grade IV Public Elementary Schools in Cluster II Sukasada District who follow the NHT learning model is higher than students who follow the conventional learning model, 2) there are differences in the learning outcomes of science in students who follow the NHT learning model with students who follow conventional learning models that have high achievement motivation, 3) there is no significant difference in the learning outcomes of science in students who follow the NHT learning model with students who follow the conventional learning model that has low achievement motivation and, 4) there is an interaction between the learning model and achievement motivation towards the learning outcomes of Natural Sciences grade IV students in the Elementary School in Cluster II Sukasada District.

The fourth hypothesis has succeeded in rejecting $\mathrm{HO}$ and accepting $\mathrm{H} 1$, this means that there are differences in social studies learning outcomes between students who are taught with the numbered head together learning model assisted by audio-visual media and students who are taught conventional learning models in students who have low learning motivation. Students who have low learning motivation tend not to have a high interest in learning, do not like to do something difficult, not happy in solving a problem, and of course difficult to understand the material provided. In line with Suratdeni, et al., (2016) which states, students who have low learning motivation lack high willingness, and tend to not understand the benefits of learning for themselves. If the application of the learning model of the numbered head together on students who have low learning motivation, the teaching and learning process is less effective, students will be passive, and not interested in learning. This is because the learning model of the numbered head together requires students to be active, able to explore their knowledge, and each student must provide his opinion in answering the problems given, and students are required to be ready in participating in learning in class. So if the numbered head together learning model is applied to students who have low motivation, students will be passive and unable to accept the material presented. In line with Artini, et all. (2019) which states, the use of inappropriate learning models can lead to boredom, the material delivered is less understood, and makes students passive, so students are less motivated. Therefore students who have low learning motivation need guidance from the teacher. The application of conventional models to students who have low learning motivation will make students feel guided and assisted in solving existing problems, this can help students in understanding learning material, and can activate and make students happy in learning, and certainly be able to optimize their learning outcomes. So it can be concluded that the 
conventional learning model is suitable for students who have low motivation. In line with Artini, et all. (2019) which states, the use of an appropriate learning model can create a learning atmosphere that is fun, interesting, activates students, engages students in learning, and motivates students.

This is in line with research conducted by Upu (2019) with the title "The Effect of Learning Models on Mathematical Learning Outcomes in Terms of Student Learning Motivation". The results of the study showed: 1) there was no effect of the interaction of cooperative learning models with students 'mathematics learning motivation on student mathematics learning outcomes, 2) students who were highly motivated to learn, there were significant differences between the results of students' mathematics being taught with CRH and NHT and, 3 ) students who are motivated to learn low, there are real differences between the mathematical results of students taught with CRH and NHT.

In the implementation of this research, it was found that through the application of the learning model of the numbered head together assisted with audiovisual media in terms of student learning motivation is a suitable model to make students active and more ready to participate in learning, to optimize the achievement of learning outcomes. The application of the numbered head together learning model assisted by audio-visual media, especially video media can attract students' attention in learning, able to create a pleasant learning atmosphere, and make students more prepared and more focused in accepting learning, so students better understand learning and learning materials become more meaningful, and can increase student motivation.

\section{Conclusions and Suggestions}

Based on the results of research and data analysis, the following conclusions are obtained. First, there are differences in social studies learning outcomes between students who are taught with the numbered head together learning model assisted by audio-visual media and students who are taught conventional learning models in class V students of Elementary School 2019/2020 Academic Year. Second, there is the effect of interaction between the numbered head together learning model assisted by audio-visual media and learning motivation towards the social studies learning outcomes of fifthgrade students of Elementary School in 2019/2020 Academic Year. Third, there are differences in social studies learning outcomes between students who are taught with the numbered head together learning model assisted by audio-visual media and students who are taught with conventional learning models in students who have high learning motivation. Fourth, there are differences in social studies learning outcomes between students who are taught with the learning model of the numbered head together assisted by audio-visual media and students who are taught with conventional learning models in students who have low learning motivation. Based on the foregoing, it can be concluded that the numbered head together learning model assisted by audiovisual media influences the acquisition of social studies learning outcomes in terms of student motivation in class V Elementary School 2019/2020 Academic Year.

The suggestions that can be submitted by researchers are as follows. For students, through the application of the NHT learning model based on audio-visual media it is recommended that students become more active and serious in learning activities, students who have better abilities so that they want to help their friends who have less ability to understand the material being taught, to optimize achievement of learning outcomes, especially on social studies subject content. For teachers, it is suggested that applying innovative learning models, one of them is by applying numbered head together learning models assisted by audio-visual media, to create a pleasant learning atmosphere and be able to optimize the acquisition of student learning outcomes. For schools, it is suggested to be able to provide training for teachers on the numbered head together learning models that are assisted by audiovisual media, so that this model can be applied to all classes. For other researchers who want to research with the numbered head together learning model, it is recommended that innovations be made for the next learning process.

\section{References}

A.M., S. (2011). Interaksi dan Motivasi Belajar Mengajar. Jakarta: PT Raja Grafindo Persada.

Ali, S. (2018). Pengaruh Model Pembelajaran dan Motivasi Belajar Fisika terhadap Hasil Belajar Fisika (Studi Eksperimen Peserta Didik pada Kelas VIII SMP Negeri 40 Bulukumba). Jurnal Pendidikan MIPA, 8(1), 15-28.

Artini, R. J., Adnyana, P. B., \& Warpala, I. S. (2019). Pengaruh Model Pembelajaran Make A Match Berbantuan Media Couple Card Terhadap Motivasi Belajar dan Hasil Belajar Biologi Materi 
Sistem Ekskresi pada Manusia Siswa Kelas XI SMA Negeri 2 Banjar. Jurnal Pendidikan Biologi Undiksha, 6(1), 33-43.

Astuti, W. (2019). Pengaruh Model Numbered Heads Together (NHT) Terhadap Motivasi Belajar dan Hasil Belajar IPS Siswa Kelas III Sekolah Dasar. Jurnal Basicedu, 3(2), 605-610.

Erlinda, N., \& Nastuti, R. (2018). The Effect of Numbered Heads Together to Junior High School Students'natural Sciences Competencies of SMPN 2 Batang Anai Based Their Preliminary Knowledge. Proceeding Iain Batusangkar, 1(2), 339-346.

Fauziah, R. (2018). Effect Of Cooperative Learning Model Numbered Heads Together (NHT) Type On Student Learning Outcomes In Social studies Subjects In Grade V Elementary School. International Journal of Educational Dynamics, 1(1), 147-154.

Hasmyati, S. (2017). Comparative Cooperative Learning Type NHT (Numbered Head Together) and TAI (Team Assisted Individualization) Volleyball Classes at Junior High School in Makassar, Indonesia. International Journal of Science and Research (IJSR), 6(9).

Iqbal, I., Sahyar, S., \& Sudrajat, A. (2017). The Effect of Cooperative Learning Model Type Numbered Heads Together (NHT) Assisted Media Video and Motivation on Natural Science Achievement of Elementary School Students. Advances in Social studies, Education and Humanities Research, 104.

Kistian, A. (2018). Pengaruh Model Pembelajaran Numbered Head Together (NHT) Terhadap Hasil Belajar Matematika Siswa di Kelas IV SDN 4 Banda Aceh. Genta Mulia: Jurnal Ilmiah Pendidikan, $9(2)$.

Mahardika, I. P. M., Dantes, N., \& Widiana, I. W. (2018). Pengaruh Model Pembelajaran Numbered Heads Together Terhadap Hasil Belajar IPS pada Siswa Kelas V SD Gugus V Kintamani Tahun Pelajaran 2017/2018. Mimbar PGSD, 6(1).

Mardyastuti, A., Suarni, N. K., \& Parmiti, D. P. (2016). Pengaruh Model Pembelajaran NHT dan Motivasi Berprestasi terhadap Hasil Belajar IPA Siswa Kelas IV. E-Journal PGSD Universitas Pendidikan Ganesha, 4(2).

Nugraha, A. J., Suyitno, H., \& Susilaningsih, E. (2017). Analisis Kemampuan Berpikir Kritis Ditinjau dari Keterampilan Proses Sains dan Motivasi Belajar melalui Model PBL. Journal of Primary Education, 6(1), 35-43.

Nuryanti, S., \& Mustapa, K. (2018). Effect of Number Head Together and Talking Stick Types of Cooperative Learning Model on Redoks Towards Student's Motivation and Learning Outcomes. Advances in Social studies, Education and Humanities Research, 174.

Oktaviani, M. D. S., Suwatra, I. W., \& Murda, N. (2019). Pengaruh Model Pembelajaran Snowball Throwing Berbantuan Media Audiovisual terhadap Hasil Belajar Bahasa Indonesia. Jurnal Ilmiah Sekolah Dasar, 3(1), 89-97.

Paramita, D. K., Garminah, N. N., \& Wibawa, I. M. C. (2016). Penerapan Model Pembelajaran Kooperatif Tipe NHT Berbantuan Media Audio Visual untuk Meningkatkan Hasil Belajar IPA. E-Journal PGSD Universitas Pendidikan Ganesha Jurusan PGSD, 4(1).

Purwati, N. L. P. D., Wibawa, I. M. C., \& Margunayasa, I. G. (2019). Pengaruh Numbered Head Together Berbantuan Gambar Terhadap Penguasaan Kompetensi Pengetahuan IPA. Jurnal Pedagogi Dan Pembelajaran, 2(3), 282-292.

Rahayu, S., \& Suningsih, A. (2018). The Effects of Type Learning Model Numbered Head Together and Think Pair Share. International Journal of Trends in Mathematics Education Research, 1(1), 19-21.

Rositayani, N. P. E., Putra, D. B. K. N. S., \& Abadi, I. B. G. S. (2018). Pengaruh Model Pembelajaran Children's Learning in Science berbantuan Media Audio Visual terhadap Kompetensi Pengetahuan IPA. Jurnal Ilmiah Sekolah Dasar, 2(3), 338-346.

Selamet, N. W., Tegeh, I. M., \& Dharmayanti, P. A. (2017). Pengaruh Model Pembelajaran Numbered Head Together Berbasis Tri Kaya Parisudha Terhadap Hasil Belajar IPS Siswa Kelas IV. Mimbar $P G S D, 5(2)$.

Setianingsih, I. G. A. A., Putra, D. K. N. S., \& Ardana, I. K. (2019). Pengaruh Model Pembelajaran Reciprocal Teaching Berbantuan Media Audio Visual terhadap Kompetensi Pengetahuan IPA. Journal of Education Technology, 3(3), 203-209. 
Sindy Karina, D. E. W. I. (2017). Pengembangan Media Pembelajaran Question Card Kompetensi Dasar Mengidentifikasi Alat dan Bahan Kearsipan pada Siswa Kelas X Apk 2 SMK Adhikawacana Surabaya. Jurnal Administrasi Perkantoran, 5(2).

Siregar, M., Saragih, A. H., \& Situmorang, J. (2019). Pengaruh Strategi Pembelajaran Kooperatif Numbered Head Together dengan Student Teams Achievement Division dan Kecerdasan Ganda Terhadap Hasil Belajar IPS. Jurnal Teknologi Pendidikan, 12(1), 75-87.

Sugihatno, A. C. M. S., \& Slamet, I. (2017). Realistic Matematic Approach through Numbered Head Together Learning Model. Journal of Physics: Conference Series, International Conference on Mathematics and Science Education (ICMScE), 895(1).

Sugiyadnya, I. K. J., Wiarta, I. W., \& Putra, I. K. A. (2019). Pengaruh Model Pembelajaran Kooperatif Learning Tipe NHT terhadap Pengetahuan Matematika. International Journal of Elementary Education, 3(4), 413-422.

Suratdeni, N. K., Kusmariyatni, N., \& Japa, I. G. N. (2016). Pengaruh Model Team Assisted Individualization Berbantuan Media Gambar Terhadap Hasil Belajar Ipa Ditinjau dari Motivasi. Mimbar PGSD, 4(1).

Susanto, A. (2014). Teori Belajar dan Pembelajaran di Sekolah Dasar. Jakarta: Prenadamedia Group.

Tayeb, T. (2017). Analisis dan manfaat model pembelajaran. AULADUNA. Jurnal Pendidikan Dasar Islam, 4(2), 48-55.

Trianto. (2010). Mendesain Model Pembelajaran Inovatif-Progresif. Jakarta: Kencana Prenada Media Group.

Trisianawati, E., Djudin, T., \& Stianingsih, Y. D. (2018). Pengaruh Penerapan Model Pembelajaran Numbered Head Together (NHT) terhadap Hasil Belajar Siswa. Berkala Ilmiah Pendidikan Fisika, 6(3), 354-361.

Trisnawati, T., Sari, W. R., \& Utami, B. H. S. (2019). The Enhancement of Learning Mathematic's Motivation by Using Application of Quantum Learning Model Teaching. International Journal of Trends in Mathematics Education Research, 2(4), 197-201.

Upu, H., Sappaile, B. I., \& Akhmad, H. (2019). Pengaruh Model Pembelajaran Terhadap Hasil Belajar Matematika Ditinjau dari Motivasi Belajar Siswa. Issues in Mathematics Education, 2(2), 152-160.

Utama, K. S. W., Parmiti, D. P., \& Japa, I. G. N. (2019). Pengaruh Model Pembelajaran Nature Of Science Berbantuan Media Video Terhadap Hasil Belajar IPA Siswa Kelas V. Journal of Education Technology, 2(3), 112-119.

Utami, T., Kristin, F., \& Anugraheni, I. (2018). Penggunaan Model Pembelajaran Kooperatif Tipe Numbered Head Together (NHT) pada Pembelajaran Matematika untuk Meningkatkan Motivasi Belajar dan Hasil Belajar Siswa Kelas IV. JUSTEK Jurnal Sains Dan Teknologi, 1(1), 82-88.

Wahida, S. N., Ramly, R., \& Halim, M. (2019). Perbedaan Hasil Belajar IPS Menggunakan Model Problem Based Learning (PBL) dan Model Pembelajaran Kooperatif Tipe Number Head Together (NHT) Ditinjau dari Kreativitas Belajar Siswa Kelas VIII SMP 2 Raha. Jurnal Wahana Kajian Pendidikan IPS, 3(1).

Widyaningtyas, H., Winarni, R., \& Murwaningsih, T. (2018). Developing Students' Responsibility Through Numbered Head Together Model In Social studies Learning At Elementary School. International Journal of Indonesian Education and Teaching, 2(2), 112-119.

Wijayanto, S. M. (2017). Pengaruh Penggunaan Model Pembelajaran Discovery Learning Terhadap Hasil Belajar IPA Kelas V SDN Bintoro 4 Demak. Magistra, 8(1), 56-76. 